\title{
The Economical Feasibility of Large Animal Composting
}

\author{
Joe L. Parcell ${ }^{1}$, Joe Horner ${ }^{1}$, Ryan Milhollin ${ }^{1} \&$ Jason Franken ${ }^{2}$ \\ ${ }^{1}$ Department of Agricultural Economics, University of Missouri, Columbia, United States \\ ${ }^{2}$ Agricultural and Industrial Sciences, Sam Houston State University, Huntsville, United States \\ Correspondence: Joe L. Parcell, Department of Agricultural and Applied Economics, University of Missouri, \\ Columbia, MO, 65211, United States. Tel: 1-573-882-0870. Fax: 573-884-6572. E-mail: parcellj@missouri.edu
}

Received: October 23, 2014 Accepted: March 9, 2015 Online Published: April 15, 2015

doi:10.5539/jas.v7n5p19 URL: http://dx.doi.org/10.5539/jas.v7n5p19

\begin{abstract}
This study examines the economic feasibility of 4 alternative large animal mortality composting systems that a producer-owned entity could potentially operate. The 4 systems evaluated are a vertical mechanical composter (Dutch Composter), a horizontal mechanical composter (BIOvator ${ }^{\mathrm{TM}}$ ), an open static pile yard and a roofed or covered static pile yard. This study includes a 5 -year pro forma financial analysis and suggests recommendations regarding the most economically viable and environmentally appropriate alternatives. Based on the financial analysis and the current regulatory environment, the recommended compost system for a regional animal mortality facility is static piles under roof. However, alternative technologies may be feasible in other scenarios.
\end{abstract}

Keywords: animal mortality, composting, dead animal disposal, economic feasibility, large animal

\section{Introduction}

In Missouri, all animal mortalities must be properly disposed within 24 hours. Five disposal options that have been acceptable, in order of preference, are rendering, composting, land filling, incineration, and burial (Fulhage, 1994). Based on the U.S. Department of Agriculture's 2007 Census of Agriculture livestock estimates, Missouri State Highway Patrol 2007 data on deer-related accidents, and assumptions regarding death losses and average animal sizes, Missouri annual beef, dairy, hog, horse, and deer mortalities total 264.9 million $\mathrm{kg}$ and require proper disposal (Figure 1). Burial is challenging due to equipment needs and geographic restrictions. Few Missouri renderers, commercial incinerators, and landfills allow dead animal disposal. Several renderers ceased operations due to lower hide values linked to the recession and higher disposal costs associated with U.S. Food and Drug Administration (FDA) regulations issued April 27, 2009 (Note 1). These events caused the industry to lack traditional animal disposal means. 


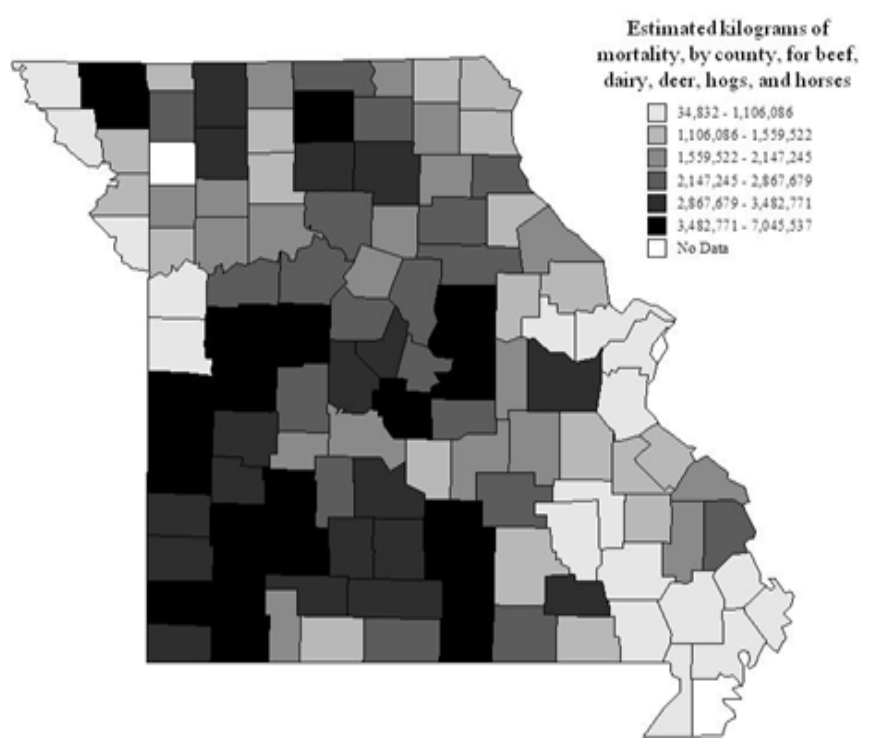

Figure 1. Kilograms of large animal mortalities in Missouri by county

Kilograms of large animal mortalities in Missouri by county. In Missouri, annual estimated beef, dairy, hog, horse, and deer mortalities total 264.9 million $\mathrm{kg}$.

Legend: Estimated kilograms of mortality, by county, for beef, dairy, deer, hogs, and horses; 34,832 to $1,106,086$; $1,106,086$ to $1,559,522 ; 1,559,522$ to $2,147,245 ; 2,147,245$ to $2,867,679 ; 2,867,679$ to $3,482,771 ; 3,482,771$ to $7,045,537$.

One study evaluated dead animal disposal costs as a future threat for Arkansas stocker cattle operators. On a 1 to 5 scale - 1 meaning not at all important and 5 meaning extremely important - stocker cattle operators on average scored dead livestock disposal costs a 3.2 (Troxel et al., 2007). Animal disposal acceptance is a potential challenge. A Pennsylvania study asked participating beef, veal, dairy, poultry, and swine producers whether they'd fielded comments or complaints about their operations within the past 2 years. On average, 25.9 percent had received comments or complaints, and 0.5 percent specifically noted receiving dead livestock disposal comments or complaints (Nordstrom et al., 1999).

Composting can be an environmentally compatible, low-capital option for dead animal disposal. Understanding composting processes, implementation, and costs is necessary before making a composting facility investment. This study evaluates the economic feasibility of 4 large animal composting systems.

\section{Materials and Methods}

To assess the economic viability of a dead animal composting facility, this study used interview and economic modeling methods. It considers the revenue and costs associated with operating 4 large animal composting systems: a vertical mechanical composter (Dutch Composter), a horizontal mechanical composter (BIOvator ${ }^{\mathrm{TM}}$ ), an open static pile yard, and a roofed or covered static pile yard. Figure 2 diagrams a possible composting business supply chain that a farmer cooperative could operate. Not only could farmers themselves use a composting facility, but livestock auction operators and small-scale meat processors are also potential customers. A well-designed composting facility that uses sawdust, woodchips, and other carbon sources could significantly increase efficiency and enable good throughput for dead animal mortalities.

In each of these systems, the costs and composting speeds differ, but each requires a carbon source (wood chips, sawdust, hay, etc.) to ensure a proper carbon-to-nitrogen ratio and enable carcasses to decompose into soil amendments. Mechanical systems are popular in Canada, which has enacted strict rendering and disposal regulations. They've also been adopted by some large livestock complexes where arrival of dead animal pickup vehicles entails bio-security concerns that outweigh the high capital costs of mechanical systems. Piles are typically less expensive, but they lengthen the decomposition timeline, particularly when cooler weather slows the biological processes that lead to carcasses decomposing. Open static piles are the simplest, cheapest system. Covered static piles are similar, except composting takes place under a roof and on an impervious layer of packed clay, asphalt, or concrete. A roofed system is more environmentally conscious because it eliminates 
runoff caused when rainfall reaches a pile. Under roof, compost moisture levels are easier to control, which creates more ideal composting conditions.

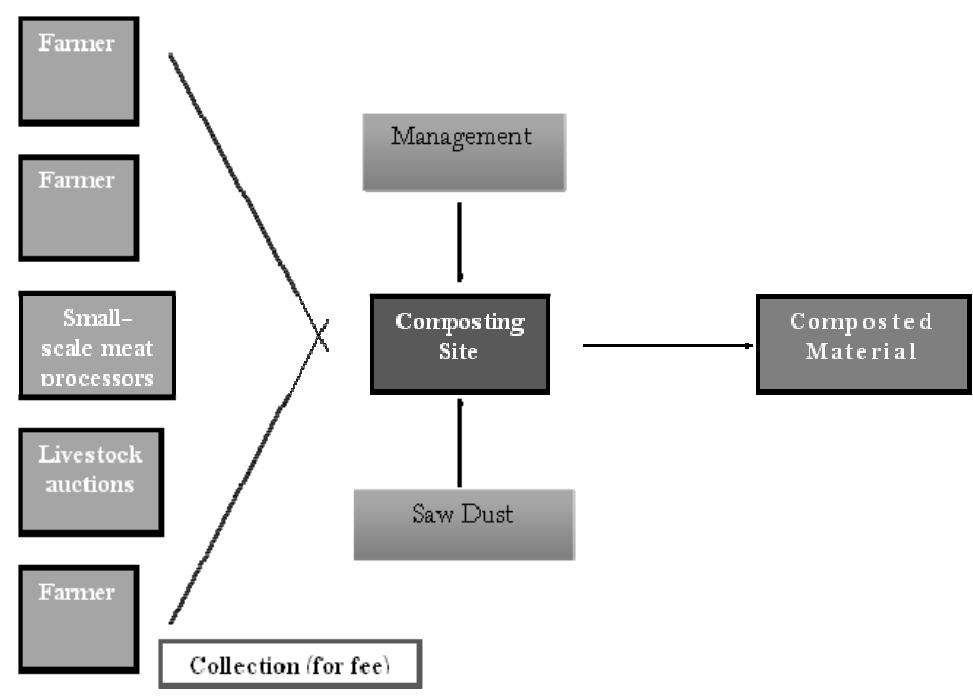

Figure 2. Composting business supply chain

Composting business supply chain. This schematic presents one possible composting business supply chain that a farmer cooperative could operate.

The composting process yields two main products: hides and the compost itself. The value of these products contributes to a large animal composting enterprise's economic viability. Skinning carcasses accelerates the composting process and provides additional value to the overall mortality composting enterprise. Hides usually sell for $\$ 40$ to $\$ 55$ per hide, but price may vary somewhat by region (Figure 3). The economic downturn in 2008 caused hide prices to plummet; however, they've since started to recover. The hide sales revenue stream would be influenced by economic conditions and could be uncertain.

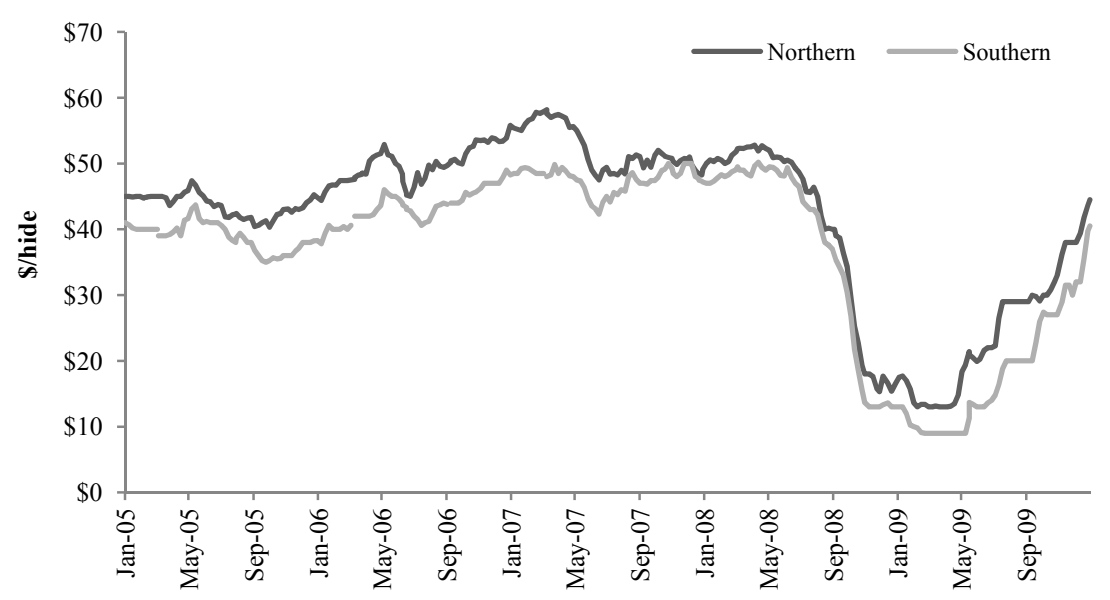

Figure 3. Heavy native cow U.S. hide prices (\$/hide)

Heavy native cow U.S. hide prices (\$hide). Hide values would contribute to a large animal composting enterprise's economic viability.

Legend: Northern price per hide and southern price per hide.

Source: The Jacobsen Publishing Company, 2010. 
High-value markets for compost, such as horticultural uses, typically require mixtures that deliver nutrients that promote plant growth. Table 1 presents compositional analyses for the composting mixture, which includes a carbon feedstock, before animal composting has occurred and after the process is complete.

Table 1. Composting mixture composition before and after composting

\begin{tabular}{|c|c|c|c|c|c|c|c|c|}
\hline \multirow{2}{*}{ Nutrient } & \multicolumn{4}{|c|}{ Before composting } & \multicolumn{4}{|c|}{ After composting } \\
\hline & $\overline{\text { Sample \#1 }}$ & Sample \#2 & Sample \#3 & Average & Sample \#1 & Sample \#2 & Sample \#3 & Average \\
\hline Carbon (\%) & 42.8 & 47.8 & 4.3 & 44.8 & 17.9 & 18.1 & 28.9 & 21.6 \\
\hline Nitrogen (\%) & 4.2 & 3.4 & . & 3.8 & 2.3 & 1.3 & 2.3 & 2 \\
\hline $\mathrm{C}: \mathrm{N}$ & $10: 01$ & $14: 01$ & . & $12: 01$ & $8: 01$ & $14: 01$ & $13: 01$ & $11: 01$ \\
\hline Phosphorus (\%) & 0.01 & 0.01 & . & 0.01 & 0.01 & 0.01 & 0.04 & 0.02 \\
\hline Dry matter (\%) & 19.4 & 25.4 & 21.7 & 22.2 & 40.4 & 47.5 & 51.4 & 46.4 \\
\hline $\mathrm{pH}$ & 8.5 & 8.4 & 8 & 8.3 & 8.6 & 8.7 & 8.2 & 8.5 \\
\hline
\end{tabular}

Source: Looper, Fitzgerald, and Rogers (2002). Composting of bovine mortalities on New Mexico dairies. Paper presented at the annual meetings of the Western Section of the American Society of Animal Science, Fort Collins, $\mathrm{CO}$.

Notably, the process does not yield high levels of nitrogen and phosphorus, which are key nutrient components important for plant growth. Instead, it mostly contributes dry matter. Table 2 shares nitrogen levels and pricing for organic ruminant compost compared with nitrogen content and pricing of other fertilizers.

Table 2. Economic comparison of organic ruminant compost with other fertilizers

\begin{tabular}{llllll}
\hline Fertilizer & $\%$ nitrogen & kg nitrogen/100kg & price/100 kg of product & price/kg nitrogen & $\mathrm{kg}$ nitrogen/\$1.00 \\
\hline Alfalfa meal & $2.4 \%$ & 2.4 & $\$ 83.60$ & $\$ 34.83$ & 0.03 \\
Blood meal & $12 \%$ & 12 & $\$ 198.00$ & $\$ 16.5$ & 0.06 \\
Fertrell 3-2-3 & $3 \%$ & 3 & $\$ 83.60$ & $\$ 27.87$ & 0.04 \\
Fish meal & $8 \%$ & 8 & $\$ 114.40$ & $\$ 14.30$ & 0.07 \\
Soybean meal & $7 \%$ & 7 & $\$ 123.20$ & $\$ 17.60$ & 0.06 \\
Chemical lawn fertilizer & $10 \%$ & 10 & $\$ 55.00$ & $\$ 5.50$ & 0.18 \\
Ruminant compost & $2 \%$ & 2 & $\$ 3.21^{1}$ & $\$ 1.61^{\mathrm{a}}$ & 0.62
\end{tabular}

Note. ${ }^{1}$ Imputed from lowest value of commercial compost available in bulk (conversion is $\$ 31.90 /$ tonne of product).

Relative to the other fertilizers analyzed, ruminant compost is among the least nitrogen-rich, and as such, it has the lowest assumed fertilizer value per unit. Although ruminant compost seems price competitive in terms of cost per part nitrogen, significant nitrogen quantities would be needed given the ruminant compost's high proportion of dry matter. Due to animal-based compost's low fertilizer value and potential zoonotic disease liability, its use in high-end horticultural markets is not advisable unless it is further processed. Such heat processing would add substantial costs, however. Still, the ruminant compost's nutrient composition is sufficient for nearby farmers to use such compost as a soil amendment if they can pick it up from the composting site for free. Thus, the compost would not be a revenue source, but it also would not pose a cost as farmers would provide free removal. 
Table 3. Characteristic comparison of available carbon sources

\begin{tabular}{llll}
\hline & C:N & Moisture content $(\%)$ & Bulk density $\left(\mathrm{kg} / \mathrm{m}^{3}\right)$ \\
\hline Sawdust & $276: 1$ & 41.0 & 237.31 \\
Fescue hay & $39: 1$ & 12.1 & 403.43 \\
Straw & $33: 1$ & 14.5 & 134.67 \\
Corn stalks & $67: 1$ & 12.0 & 18.98 \\
Cardboard & $563: 1$ & 8.0 & 153.66 \\
Newsprint & $625: 1$ & 6.0 & 129.33
\end{tabular}

Source: Zulovich (2009). Personal Communication. Division of Food Systems and Bioengineering, University of Missouri.

Composting is an aerobic process. Selecting the best biomass feedstock to use for composting depends on price, availability, and ease of use. Composting requires a carbon-to-nitrogen (C:N) ratio range between 20:1 and 40:1. The C:N ratios of all ingredients used in the composting recipe must be known and mixed in roughly correct proportions for the process to proceed efficiently. Moisture content in the 50 percent to 60 percent range is desirable for piles to efficiently compost material. Cattle's body composition is approximately 55 percent water. Efficient composting operations make special efforts to utilize recipes that achieve a moisture content and C:N ratio in the optimum ranges. Bulk density of composting ingredients is another useful property. The moisture content, C:N ratio, and bulk density of six carbon sources are shown in Table 3.

Halfway Packing Company, interviewed early in 2010, indicated that the cost to operate a covered truck pickup route that accumulates dead animals is about $\$ 0.9321$ per $\mathrm{km}$. Respondents reported that established routes into livestock concentration areas usually yielded about $4,535.92 \mathrm{~kg}$ of dead animals. A typical route required about $563.27 \mathrm{~km}$ of travel to fill the truck. Mortality pickup costs, based on these surveys, would be approximately $\$ 0.11$ per kg. At this rate, a 544.31-kg carcass would incur an average $\$ 60$ pickup charge. Lower carcass pickup costs could be realized by shortening haul distances or loading multiple mortalities from a single site. Hauling costs may be a major economic factor that influences centralized dead animal disposal options, especially if the carcass rendering value is low and does not provide adequate income to offset the transportation costs.

In the following analysis, all four systems were assumed to be built in a facility capable of handling one dead cow per day. This was the minimum starting point thought to be practical. Specifying a facility that handles one cow per day allows for comparing each system on an equivalent basis. All systems are scalable simply by adding more mechanical compost units or adding more compost pile space. A $\$ 75$ processing fee per $680.39 \mathrm{~kg}$ of animal mortality composted is assumed. This fee is not adjusted for potential inflation in the financial analysis. The financial analysis does not explicitly include a route truck or account for transporting dead animals from their original location to the compost site. It does, however, provide an investment option for a covered trailer that could transport dead animals, and it discusses the effect of potential government subsidies.

Table 4 lists capital costs for each composting system considered. As noted earlier, the systems can manage one $680.39-\mathrm{kg}$ dead cow per day, and they are scalable by adding more mechanical compost units or more compost pile space. For each system, a $\$ 50,000$ working capital investment is assumed as a beginning cash balance, and each system has the same basic land and improvements requirements. These requirements include two acres that are graded, landscaped, and graveled to control water run-off issues. The site must be fenced and gated to control access, and each system requires a connection to electricity and water. For the Dutch Composter system, a concrete pad, on which the Dutch Composter would be erected, is an additional cost. Each system also uses a shipping container for equipment storage and office space, and each requires a payloader to move carcasses and carbon sources. Similar costs are also assumed across systems for miscellaneous tools and equipment. Major differences in each system's capital costs are due to varying building and machinery costs.

As the most simplistic system, open static piles incur no building costs other than the aforementioned shipping container for equipment storage and office space. Both the Dutch Composter and BIOvator ${ }^{\mathrm{TM}}$ systems include a $^{2}$ $92.90 \mathrm{~m}^{2}$ building with a concrete floor that would store finished compost up to 60 days. The covered composting system is operated within a $1,393.5 \mathrm{~m}^{2}$ roofed facility, which is the largest cost of that system.

Machinery is the major cost involved in a mechanical composting system. The Dutch Composter completely composts a cow within 4 days, and hence, 4 units are required to handle an inflow of 1 cow per day. In 
comparison, a single BIOvator ${ }^{\mathrm{TM}}$ unit has the capacity to compost $680.39 \mathrm{~kg}$ of mortality per day, and thus, 3 BIOvator $^{\mathrm{TM}}$ units are needed to handle an inflow of 1 cow per day. For static pile-based systems, another pile may be initiated daily to increase capacity. The Dutch Composter base unit costs $\$ 48,300$, excluding shipping warranty, optional features, and installation costs. This analysis assumes the estimated installed cost to be $\$ 60,000$ per unit. A single BIOvator ${ }^{\mathrm{TM}}$ unit costs $\$ 50,000$. Both mechanical systems require an auger elevator to safely move finished compost from the machines to storage. The Dutch Composter, however, does not incur a screener expense required by the other systems because it fully grinds bones into thumbnail-sized or smaller pieces. As summarized in Table 4, the Dutch Composter has the highest startup costs, the BIOvator ${ }^{\mathrm{TM}}$ and roofed piles have similar costs, and open piles have the lowest startup costs.

Table 4. Comparison of capital costs across composting systems

\begin{tabular}{|c|c|c|c|c|}
\hline Capital investments & Dutch composter & Biovator $^{\mathrm{TM}}$ & Open piles & Roofed piles \\
\hline \multicolumn{5}{|l|}{ Land and improvements } \\
\hline -Land $(0.8$ hectare $\times \$ 4,940$ per hectare $)$ & $\$ 4,000$ & $\$ 4,000$ & $\$ 4,000$ & $\$ 4,000$ \\
\hline -Fence and gate & $\$ 1,500$ & $\$ 1,500$ & $\$ 1,500$ & $\$ 1,500$ \\
\hline -Landscaping & $\$ 1,000$ & $\$ 1,000$ & $\$ 1,000$ & $\$ 1,000$ \\
\hline -Gravel area & $\$ 4,000$ & $\$ 4,000$ & $\$ 4,000$ & $\$ 4,000$ \\
\hline -Land grading & $\$ 2,000$ & $\$ 2,000$ & $\$ 2,000$ & $\$ 2,000$ \\
\hline -Electrical connection & $\$ 1,500$ & $\$ 1,500$ & $\$ 1,500$ & $\$ 1,500$ \\
\hline -Water source (PWS connection, pond or well) & $\$ 7,000$ & $\$ 7,000$ & $\$ 7,000$ & $\$ 7,000$ \\
\hline -Concrete pad for Dutch Composter ( $2.44 \mathrm{~m}$ by $2.44 \mathrm{~m}$ by $0.15 \mathrm{~m})$ & $\$ 1,200$ & & & \\
\hline \multicolumn{5}{|l|}{ Buildings } \\
\hline - Shipping container (storage, office, etc.) & $\$ 1,500$ & $\$ 1,500$ & $\$ 1,500$ & $\$ 1,500$ \\
\hline - Composting facility $\left(1,393.55 \mathrm{~m}^{2} \times \$ 10\right)$ & & & & $\$ 13,935.50$ \\
\hline - Covered (finished compost) storage & $\$ 10,000$ & $\$ 10,000$ & & \\
\hline \multicolumn{5}{|l|}{ Machinery } \\
\hline - Biovater ${ }^{\mathrm{TM}}$ (3 units) & & $\$ 150,000$ & & \\
\hline - Dutch Composter (4 units) & $\$ 240,000$ & & & \\
\hline - Screener & & $\$ 1,100$ & $\$ 1,100$ & $\$ 1,100$ \\
\hline - Auger elevator & $\$ 1,000$ & $\$ 1,000$ & & \\
\hline - Payloader & $\$ 20,000$ & $\$ 20,000$ & $\$ 20,000$ & $\$ 20,000$ \\
\hline - Misc. tools and equipment & $\$ 1,000$ & $\$ 1,000$ & $\$ 1,000$ & $\$ 1,000$ \\
\hline Total capital investment & $\$ 295,700$ & $\$ 205,600$ & $\$ 44,600$ & $\$ 194,600$ \\
\hline Working capital investments & $\$ 50,000$ & $\$ 50,000$ & $\$ 50,000$ & $\$ 50,000$ \\
\hline Total startup investment & $\$ 345,700$ & $\$ 255,600$ & $\$ 94,600$ & $\$ 244,600$ \\
\hline Per $680.39 \mathrm{~kg}$ of mortalities & $\$ 81.01$ & $\$ 56.33$ & $\$ 12.22$ & $\$ 53.32$ \\
\hline
\end{tabular}

Table 5 displays 2011 operational expenses for each composting system. Each system is configured to accept one 680.39-kg cow per day or 365 mature cows per year. A $\$ 10$ per hour labor rate is assumed for an employee working 1 hour per day to operate the facility. Other operational inputs necessary for composting the animal mortalities are electricity and a carbon source. Electricity expenses are computed based on usage information supplied by the mechanical composter manufacturers and local electricity rates (Energy Information Administration). Electricity expenses for the Dutch Composter are notably higher than the BIOvator ${ }^{\mathrm{TM}}$. No electricity expenses are assumed for static pile-based systems. Carbon source expenses reflect identical compost system requirements of $226 \mathrm{~kg}$ per animal composted and an average price of $\$ 35$ per tonne for local carbon sources. An annual \$500 miscellaneous fuel expense covers regional travel to secure carbon source materials and 
other administrative travel expenses. This fuel expense does not include the expense of operating a route truck, as noted earlier. Other operational expenses shown in Table 5 are estimates. An annual inflation rate of 3 percent is applied to each expense in the second year to fifth year shown in the financial analysis. Operational costs for the Dutch Composter are about 3 times the operational costs of the other composting systems.

Table 5. Comparison of operating costs across composting systems

\begin{tabular}{|c|c|c|c|c|}
\hline Cash operating costs & Dutch Composter & BIOvator $^{\mathrm{TM}}$ & Open piles & Roofed piles \\
\hline Employee (1 hour per day $\times \$ 10$ per hour) & $\$ 3,650$ & $\$ 3,650$ & $\$ 3,650$ & $\$ 3,650$ \\
\hline Electricity $^{\mathrm{a}}$ & $\$ 21,900$ & $\$ 600$ & & \\
\hline Carbon $(\$ 38.50 /$ tonne $\times 0.23$ tonnes of carbon $/$ day $\times 365$ days $)$ & $\$ 3,194$ & $\$ 3,194$ & $\$ 3,194$ & $\$ 3,194$ \\
\hline Fuel (excluding route truck) & $\$ 500$ & $\$ 500$ & $\$ 500$ & $\$ 500$ \\
\hline Maintenance/repairs & $\$ 1,500$ & $\$ 1,000$ & $\$ 1,000$ & $\$ 1,000$ \\
\hline Insurance & $\$ 500$ & $\$ 500$ & $\$ 500$ & $\$ 500$ \\
\hline Taxes & $\$ 500$ & $\$ 500$ & $\$ 500$ & $\$ 500$ \\
\hline Total (annual) & $\$ 31,744$ & $\$ 9,944$ & $\$ 9,344$ & $\$ 9,344$ \\
\hline Per $680.39 \mathrm{~kg}$ of mortalities & $\$ 86.97$ & $\$ 27.24$ & $\$ 25.60$ & $\$ 25.60$ \\
\hline Depreciation and operating expenses (per $680.39 \mathrm{~kg}$ ) & $\$ 167.98$ & $\$ 83.57$ & $\$ 37.82$ & $\$ 78.91$ \\
\hline Composting service charge (\$50 per $92.9 \mathrm{~kg})$ & $\$ 75.00$ & $\$ 75.00$ & $\$ 75.00$ & $\$ 75.00$ \\
\hline Net income (per $680.39 \mathrm{~kg}$ of moralities) & $-\$ 92.98$ & $-\$ 8.57$ & $\$ 37.18$ & $-\$ 3.91$ \\
\hline
\end{tabular}

Note. ${ }^{a}$ Electricity costs are $\$ 60$ per animal to operate the Dutch Composter and $\$ 1.65$ per animal for the BIOvator $^{\mathrm{TM}}$.

\section{Results and Discussion}

A 5-year financial statement summary, based on the previously defined assumptions and projections, is given in Table 6. The initial investment is assumed to occur in 2011, and a 3 percent annual inflation rate was applied to all expenses and revenue from 2012 to 2015.

Table 6. Five year financial analysis based on assumptions presented in Tables 4 and 5

\begin{tabular}{lllll}
\hline Financial parameter & Dutch Composter & BIOvator ${ }^{\mathrm{TM}}$ & $\begin{array}{l}\text { Static compost piles } \\
\text { (unroofed) }\end{array}$ & $\begin{array}{l}\text { Static compost piles } \\
\text { (under roof) }\end{array}$ \\
\hline Initial capital investments & $\$ 345,700$ & $\$ 255,600$ & $\$ 94,600$ & $\$ 244,600$ \\
Operating expenses (year 5) & $\$ 30,696$ & $\$ 21,686$ & $\$ 5,586$ & $\$ 20,585$ \\
Net income (year 5) & $(\$ 37,923)$ & $(\$ 4,376)$ & $\$ 12,399$ & $(\$ 2,601)$ \\
Net cash flow (year 5) & $(\$ 8,353)$ & $\$ 16,183$ & $\$ 16,858$ & $\$ 16,858$ \\
\hline
\end{tabular}

Operating expenses entail general expenses (i.e., insurance and taxes) and depreciation, which is calculated using the straight-line method, a 10-year useful life, and $\$ 0$ salvage value. Income is assumed to be equivalent for each system. It represents the revenues from the $\$ 75$ processing fee charged on each $680.39-\mathrm{kg}$ carcass received. Thus, at one carcass per day, annual revenue is $\$ 27,375$ (=\$75 $\times 365$ days). Due to low nutrient (nitrogen and phosphorus) value and potential zoonotic disease liability associated with animal-based compost, the compost is not assumed to have commercial resale value. However, the compost's nutrient profile is sufficient for nearby farmers to utilize the compost as a soil amendment if they can pick up it for free from the composting site. Hence, the analysis assumes no cost for removing finished compost.

Net income is computed as the difference between revenue and operating and direct (i.e., electricity and carbon) costs. Similarly, net cash flow is the difference between actual cash receipts and expenditures. The Dutch Composter system is financially infeasible given these assumptions, as indicated by negative net income and 
cash flow reported in Table 6. Its infeasibility is mostly due to high electricity and depreciation costs. Positive cash flows make operating the BIOvator ${ }^{\mathrm{TM}}$ more feasible, even considering the net income loss due to depreciation expenses. Both net income and net cash flow indicate that open static piles are financially feasible. Cash flow in year 5 for roofed or covered static piles is the same as open piles, but net cash flow is negative due to costs of a roofed facility. However, the covered facility may be preferable due to environmental reasons, particularly if some initial investment could be offset by government subsidies.

Currently, a few federal and state programs offer subsidies for this type of operation. An animal composting operation may qualify for a government subsidy. A partially subsidized animal composting operation would reduce the startup investment requirement because the owner(s) investment would be reduced by the amount of subsidies received. Subsidies would not affect annual net income, cash flows, or net worth, but they would supplement the owner investment for capital expenditures required at startup.

Although not shown in the financial analysis, a route truck could be used to bring carcasses to the facility. Whether the added route truck expense would provide a positive economic advantage for the mortality composting facility is questionable. Purchasing a 1.83 -meter by 3.66 -meter enclosed utility trailer with a winch capable of handling $907.18 \mathrm{~kg}$ may be better option. A trailer and winch system could cost less than $\$ 5,000$. The composting operation could rent the trailer to customers who need to transport animal mortalities. A $\$ 5$ to $\$ 10$ daily rental fee would cover depreciation and mileage expenses associated with using the trailer, but it would not provide a significant revenue stream that would affect the operation economically.

The full feasibility study, with engineering recommendations, can be obtained from the authors upon request. Based on the financial analysis and possible future environmental regulatory issues, the recommended compost system for a regional animal mortality facility is static piles under roof. This system can operate without regard to rain, snow, or other bad weather, and it minimizes environmental risks and handling of dead animals. Furthermore, roofed barns should not present public acceptance problems. This system is the most robust in its ability to be implemented correctly with minimal management, and it offers the most flexibility of scale and dead animal throughput volume. In addition, its capital investment and operating costs are less significant than those of the 2 mechanical options. Finally, roofed buildings may be constructed with public assistance and potentially operated for decades with minimal additional repairs or investments. The results of this financial analysis depend on regulations, competitiveness, climate, and access to inputs including carbon sources. Alternative technologies may be feasible in other scenarios.

\section{Implications}

This study's results may inform industry participants of the most viable, economical dead animal disposal options available to livestock producers and handlers. Based on the financial analysis and possible future environmental regulations, the recommended compost system for a regional animal mortality facility is static piles under roof. This system can operate without regard to weather, it minimizes environmental and dead animal handling risks, and roofed facilities should not create public acceptance problems. Given other circumstances, however, an alternative composting technology may be more feasible.

\section{References}

Energy Information Administration. (2010). Average retail price of electricity to ultimate customers by end-use sector, by state. Retrieved January 20, 2010, from http://www.eia.doe.gov/cneaf/electricity/epm/table5_ 6_b.html

Fulhage, C. D. (1994). Dead animal disposal laws in Missouri. University of Missouri-Columbia, Cooperative Extension Service. Retrieved October 20, 2009, from http://extension.missouri.edu/publications/DisplayPu b.aspx?P=WQ216

Looper, M. L., Fitzgerald, A. C., \& Rogers, C. A. (2002). Composting of bovine mortalities on New Mexico dairies. Paper presented at the annual meetings of the Western Section of the American Society of Animal Science, Fort Collins, CO.

Missouri State Highway Patrol. (2007). Analysis of deer involvement in Missouri traffic crashes. Retrieved February 20, 2010, from http://www.mshp.dps.missouri.gov/MSHPWeb/SAC/pdf/2007DeerReport.pdf

Nordstrom, P. A., Wilson, L. L., Richards, M. J., Kelsey, T. W., \& Pitts, C. W. (1999). Self-Perceptions and Self-Assessments of Livestock Producers in Pennsylvania. Prof. Anim. Sci., 15, 156-163.

The Jacobsen Publishing Company. (2010). Heavy hide prices. Retrieved January 26, 2010, from http://www.thejacobsen.com 
Troxel, T. R., Lusby, K. S., Gadberry, M. S., Barham, B. L., Poling, R., Riley, T., ... Justice, T. (2007). The Arkansas Beef Industry - A Self-Assessment. Prof. Anim. Sci., 23, 104-115.

United States Department of Agriculture. (2007). Census of Agriculture (Vol. 1, p. 51). Retrieved November 21, 2009, from http://www.agcensus.usda.gov/Publications/2007/Full_Report

United States Food and Drug Administration. (2009). FDA issues final guidance for renderers on substances prohibited from use in animal food or feed. Retrieved April 30, 2009, from http://www.fda.gov/AnimalVeterinary/NewsEvents/CVMUpdates/ucm144008.htm

Zulovich, J. (2009). Personal Communication. Division of Food Systems and Bioengineering, University of Missouri.

\section{JEL Code: Q13}

\section{Notes}

Note 1. U.S. regulatory actions to safeguard against bovine spongiform encephalopathy (BSE) have significantly changed rendering companies' business practices, value of products, and costs incurred to pick up animals. Regulations require rendering operations to remove brains and spinal cords of all cattle older than 30 months if the carcass is processed for animal feed.

\section{Copyrights}

Copyright for this article is retained by the author(s), with first publication rights granted to the journal.

This is an open-access article distributed under the terms and conditions of the Creative Commons Attribution license (http://creativecommons.org/licenses/by/3.0/). 